


DOI: $10.2218 /$ pihph.1.2016.1702

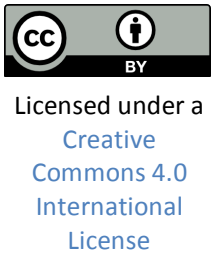

\title{
The emergence of the concept of 'morphologically conditioned sound changes'
}

\author{
MARC PIERCE \\ University of Texas at Austin
}

\begin{abstract}
One of the more controversial ideas in historical linguistics in the 1960s and 1970s was that of 'morphologically conditioned sound changes.' While Neogrammarians like Paul (1920) and Structuralists like Bloomfield (1933) had argued that sound change was exclusively conditioned by phonetic/phonological factors, some generativists (e.g. Postal 1968) rejected this claim in favor of the idea that sound change could also be morphologically conditioned. While the idea of 'morphologically conditioned sound changes' clearly resonated with many historical linguists at the time (e.g. King 1969 endorses the idea), others, like Jasanoff (1971), rejected it. More recent work on historical linguistics, e.g. Sihler (2000) and Campbell (2013), has also moved away from this idea somewhat. In this paper, I situate this idea within the history of historical linguistics in the 1960s and 1970s, focusing on generative approaches to historical linguistics. The development of the idea of morphologically conditioned sound change can be traced a number of currents in the field. Among others, it reflects (1) the increasing emphasis within phonological theory on rules over representations and (2) the intellectual heritage of the scholars involved.
\end{abstract}

\section{Introduction}

While Neogrammarians like Paul (1920) and structuralists like Bloomfield (1933) had argued that sound change was exclusively conditioned by phonetic/phonological factors, some generativists, e.g. Postal (1968), rejected this claim, contending that sound change could also be conditioned by morphological factors. In this paper, I situate this idea within the history of historical linguistics, focusing on the period 1968-1976, i.e. the time bookended by the appearance of Postal (1968) and Hock (1976), both of which are crucial works on the topic, and on generative approaches to historical linguistics. As a result, some 
important works, such as Weinreich, Labov, and Herzog (1968) and Labov $(1972,1981)$, are not discussed here. ${ }^{1}$ These chronological and philosophical bounds are occasionally overstepped here, but not often. In addition, close attention is paid to scholarly biographies, as knowing who taught what to whom can often be illuminating in linguistic historiography.

\title{
2 The Neogrammarians and the Structuralists
}

As just noted, the Neogrammarians had argued that sound change was exclusively conditioned by phonetic/phonological factors. The clearest statement of this idea is probably that found in Paul's Prinzipien der Sprachgeschichte (Paul 1920), often referred to as the 'Neogrammarian Bible':2

\begin{abstract}
Accordingly, in referring to the consistent operation of sound laws we can only mean that in phonetic change within a dialect every single case in which the same phonetic conditions exist is treated uniformly. Therefore, there are just two possibilities: (1) where the same sound occurred at an earlier time, the same sound remains at later stages of development; or (2) the sound splits into different sounds, in which case there must be a specific cause that explains why different sounds have developed in different environments. These causes must always be of a purely phonetic nature; for example, the influence of neighboring sounds, accent, and syllable position (translation by Robert W. Murray from Paul 2015: 78).
\end{abstract}

At the same time, it is clear that this neat picture did not always prevail (as Paul also admitted), and the Neogrammarians therefore left themselves several escape hatches. First, they excluded typically sporadic types of sound change like metathesis from their hypothesis, as illustrated by the following quotation from Osthoff and Brugmann (1878: xiv, fn. 1). ${ }^{3}$

\footnotetext{
1 The material in this paper will be further developed in a monograph which is currently in preparation, and these works will be treated in full there.

2 This description of Paul's work was apparently first given in Wilbur (1977: xx). The original, Paul (1920: 69), reads: "Wenn wir daher von konsequenter Wirkung der Lautgesetze reden, so kann das nur heissen, dass bei dem Lautwandel innerhalb desselben Dialektes alle einzelnen Fälle, in denen die gleichen lautlichen Bedingungen vorliegen, gleichmässig behandelt werden. Entweder muss also, wo früher einmal der gleiche Laut bestand, auch auf den späteren Entwicklungsstufen immer der gleiche Laut bleiben, oder, wo eine Spaltung in verschiedene Laute eingetreten ist, da muss eine bestimmte Ursache und zwar eine Ursache rein lautlicher Natur wie Einwirkung umgebender Laute, Akzent, Silbenstellung u. dgl. anzugeben sein, warum in dem einen Falle dieser, in dem anderen jener Laut entstanden ist."

3 This is my translation of: "Wir reden hier natürlich nur vom mechanischen lautwandel, nicht von gewissen dissimilationserscheinungen und lautversetzungen
} 
Here we are naturally only speaking about mechanical sound change, not about certain dissimilations and movements of sounds (metatheses), which are grounded in the character of the words in which they occur, are always the physical mapping of a purely mental movement, and in no way nullify the concept of sound law.

Second, they invoked mechanisms like analogy, dialect borrowing, and the later operation of other sound changes to account for other seeming exceptions to sound change (see textbooks like Campbell 2013 for additional discussion and examples). To cite a favorite textbook example of analogy, various sound changes in the history of English (Verner's Law, rhotacism) resulted in a chaotic paradigm for the verb 'choose'. In Old English, the medial consonant was a [z] in the infinitive, an [s] in the past singular, and an [r] in the past plural and past participle, but in Modern English all of these forms have a [z] as the medial consonant. This cannot be accounted for via regular sound change. Thus, the traditional account of this development is that this variation in the medial consonant has been eliminated by analogy (specifically analogical leveling, where one variant in a paradigm is generalized throughout the paradigm), such that all forms now have a [z] for the relevant consonant. ${ }^{4}$ As for dialect borrowing, it is usually invoked to account for the [v] in English vat and vixen, where [f] is expected (cf. Old English faet and fyxe(n), also German Fass and Füchsin). In Southern English dialects, fricatives were voiced wordinitially, and these forms are "rural words," suggesting that they were borrowed into the standard language from one such dialect. Finally, later sound changes can obscure the evidence for earlier ones, as in the case of Grassmann's Law and Grimm's Law in Indo-European, where Grassmann's Law in Sanskrit obscures the evidence for Grimm's Law in Germanic. 5

This idea of purely phonologically conditioned sound change was later picked up by structuralists like Leonard Bloomfield (1933). In his published work, Bloomfield successfully synthesized Neogrammarian principles with more current theoretical ideas, as in a short 1928 paper (Bloomfield 1928), in which he brilliantly refines an earlier reconstruction of the Proto-Central-Algonquin phoneme system, based

(metathesen), die in der eigenart der wörter, in welchen sie auftreten, ihre begründung haben, stets das leibliche abbild einer rein psychischen bewegung sind und den begriff des lautgesetzes in keiner weise aufheben."

${ }^{4}$ German shows a similar development in the etymologically related (and archaic) verb küren, where [r] has been generalized throughout the paradigm.

5 Grassmann's Law creates some forms, like Sanskrit bandha 'binding, bond, arrest', that seem to contradict the Germanic evidence for Grimm's Law, e.g. Gothic bindan 'bind', where Grimm's Law predicts either Sanskrit*bhandha or Gothic *pindan. 
on the application of the Neogrammarian hypothesis to newly-obtained Swampy Cree data. This brief note is particularly instructive regarding Bloomfield's views on the Neogrammarian hypothesis. Bloomfield states the problem as follows: in an earlier paper (Bloomfield 1925), he had reconstructed a number of phonemes for Proto-Central-Algonquin, but struggled with the correct reconstruction of the /ck/ phoneme (as in Fox meckusiwa 'he is red', Ojibwa mickuzi, Plains Cree mihkusiw, and Menomini mehkbn), because two of the languages (Fox and Ojibwa) show /ck/, while the other two (Plains Cree and Menomini) show /hk/. Bloomfield (1925: 152) therefore reconstructed */çk/ as the protophoneme.

In his 1928 paper, he returned to this problem. He first rejects alternative explanations grounded in analogy and borrowing, as "there appeared to be no point of contact for analogic substitution... in any of the languages, and ... borrowing of the stem for red seemed unlikely" (Bloomfield 1928: 99), leading him (1928: 99) to

\begin{abstract}
suppose that the parent speech had in this stem for red a different phonetic unit, which was symbolized by $\mathrm{P}$ [roto-]C[entral]-A[lgonquian] çk .... This supposition was necessary (or, in fact, justifiable, only on the assumption that phonemes change, i.e. that sound change goes on regardless of meaning and is therefore subject to phonetic conditions only (and is not affected by frequency, euphony, meaning, etc. or words and other forms).
\end{abstract}

Bloomfield goes on to demonstrate that the Swampy Cree data mentioned above (e.g. mihtkusiw 'he is red'), which shows /htk/ where the other languages show /ck/ or $/ \mathrm{hk} /$, confirms his PCA reconstruction of $* / c ̧ \mathrm{k} /$. His conclusion (Bloomfield 1928: 100) reaffirms his faith in the Neogrammarian hypothesis:

\footnotetext{
The postulate of sound-change without exceptions will probably always remain a mere assumption, since the other types of linguistic change (analogic change, borrowing) are bound to affect all our data. As an assumption, however, this postulate yields, as a matter of mere routine, predictions which otherwise would be impossible. In other words, the statement that phonemes change (sound-changes have no exceptions) is a tested hypothesis: in so far as one may speak of such a thing, it is a proved truth.
}

Bloomfield's later handbook, Language (Bloomfield 1933), also synthesizes Structuralist and Neogrammarian principles. It employs a structuralist view of phonemics, but also takes a clear stand in favor of the Neogrammarian hypothesis: "The limitations of these conditioned sound changes are, of course, purely phonetic, since the change 
concerns only a habit of articulatory movement; phonetic change is independent of nonphonetic factors" (Bloomfield 1933: 353-354). ${ }^{6}$

At the same time, it should be noted that Bloomfield accepted the idea that morphological factors could condition synchronic phonological rules, but not diachronic phonological changes (although Bloomfield presumably would not have conceptualized the issue as just described). Bloomfield (1930) addresses one of the thorniest problems of synchronic German phonology, the distribution of the dorsal fricatives. In the standard language, the voiceless velar and palatal fricatives in German are in near-complementary distribution, in that [x] appears following back vowels and [c] appears elsewhere, indicating that they are allophones of the same phoneme, but there are a handful of minimal pairs, e.g. Kuchen 'cake', with [x] following a back vowel, but Kuhchen 'little cow', with [c] following a back vowel, which indicate that these sounds are separate phonemes. Bloomfield's solution was not to dismiss the data, but instead to take morphology into consideration: since the [c] in Kuhchen is morpheme-initial, it can be treated as if it were word-initial, meaning that the troublesome data goes away (since [c] is the variant found word-initially). This move, while it solved the immediate problem, also violated the structuralist prohibition on using morphological information in phonemic analysis, and Bloomfield's proposal was not widely accepted (see e.g. Moulton 1947, who instead argues in favor of a 'juncture' phoneme in German, as well as Robinson 2001 for a thorough treatment of the entire problem). Although this position may seem inconsistent, it is not, since in Bloomfield's view, diachronic sound changes and synchronic phonological rules were two entirely different things. It is not until the generativist period, where diachronic sound changes and synchronic phonological rules are formalized in the same manner (and where diachronic sound change is conceived of as the application of synchronic phonological rules), that these things get lumped together.

In addition, some American Structuralists left the door open for morphologically conditioned sound changes. Edward Sapir (1921: 52), for instance, writes:

Every linguist knows that phonetic change is frequently followed by morphological rearrangements, but he is apt to assume that morphology exercises little or no influence on the course of phonetic history. I am inclined to believe that our present tendency to isolate phonetics and grammar as mutually irrelevant linguistic provinces is unfortunate. There are likely to be fundamental relations between them and their respective

6 Similar statements can be found in a number of Structuralist handbooks, as described in Postal (1968: 236-239). 


\begin{abstract}
histories that we do not yet fully grasp. After all, if speech-sounds exist merely because they are the symbolic carriers of significant concepts and groupings of concepts, why may not a strong drift or a permanent feature in the conceptual sphere exercise a furthering or a retarding influence on the phonetic drift? I believe that such influences may be demonstrated and that they deserve far more careful study than they have received.
\end{abstract}

In other words, Sapir was open to the idea of morphologically conditioned sound changes, i.e. to the idea that the Neogrammarian hypothesis might not completely hold water, and believed that further investigation was both necessary and desirable.

\title{
3 Generative approaches
}

During the development of generative approaches to historical linguistics in the 1960s, some scholars moved away from the Neogrammarian hypothesis. Here two relevant works are discussed, namely Postal (1968) and King (1969). Postal (1968: 233-234) begins his discussion with the following (presumably rhetorical) question:

\begin{abstract}
Are there quite regular and generally characterizable 'sound changes', which describe the successive states of the linguistic history of any languages, that are not describable in purely phonetic terms? That is, are there systematic changes in the phonetic output whose positions of occurrence are unstatable in terms of any set of phonetic environments although the positions of occurrence are statable if reference is made to the morphophonemic and/or superficial grammatical structure of the relevant strings?
\end{abstract}

Postal answers this question affirmatively, contending for instance, that Mohawk regularly inserts [e] to break up [kw] clusters, but not when "the [k] was the first person morpheme and the [w] the first element of the plural morpheme" (Postal 1968: 247). ${ }^{7}$ According to Postal, then, the strongest version of the Neogrammarian hypothesis, holding that sound change is exceptionless and conditioned only by phonetic/phonological factors, could not be sustained, and had to be replaced by a weaker version, namely "Some regular phonetic changes take place in environments whose specification requires reference to nonphonetic morphophonemic and/or superficial grammatical structure" (Postal 1968: 240).

King (1969) also takes up this idea. He writes that "it would be unlikely that every phonological change could be stated in terms of purely phonetic environments. And the empirical evidence bears out this prediction. Cases are not uncommon of changes that occur across

7 Postal does hedge a bit, beginning the quoted statement with "Irregularly, and for reasons which are inexplicable." 
the board except in certain morphological environments" (King 1969: 123), and discusses two sound changes that he suggests can only be accounted for in such a way. First, King looks at final schwa deletion in Yiddish. Final schwas are generally lost in Yiddish (as in forms like teg 'days', erd 'earth', gib 'I give', from Middle High German tage, erde, and gibe, respectively, but are sometimes retained, "principally when the [schwa] is an adjective inflectional ending" (King 1969: 123), e.g. dos alte land 'the old country', di groyse shtot 'the big city', etc. King (1969: 123) further states that "[a] few other final unaccented [schwas] are retained, erratically, but these too are confined to specific morphological environments, e.g. gésele 'little street', where - $(e) l e$ is the diminutive suffix." 8

King rejects other possible accounts of the Yiddish material: "[t]he retention of [schwa] in the adjective endings has nothing to do with a difference in phonetic environment. All schwas were in unstressed position, and there is no phonetic property characteristically associated with adjectives in Middle High German that might somehow account for the loss" (King 1969: 123). King also contends that an analogical account is insufficient, as "[t]here is nothing to analogize to in these cases" (King 1969: 123). In King's view, "[t]he simplest conclusion is that the environment of this change is not purely phonetic ... This, then, is a case pure and simple of phonological change that cannot be stated in terms of purely phonetic features" (King 1969: 123-124). The second change is the Mohawk data discussed by Postal (1968); King endorses Postal's analysis of the Mohawk data, stating that the sound change "applies across the board except that it is impeded in a particular morphological environment" (King 1969: 124). In sum, King, like Postal, rejects the strongest version of the Neogrammarian hypothesis, in favor of the weaker version, namely that "phonological change is regular, but its environment cannot always be stated in strictly phonetic terms" (King 1969: 121).

\section{Anttila (1972)}

The final work to discuss here was apparently the first Anglophone handbook to endorse the idea that sound change could be morphologically conditioned, Anttila (1972), who also argues that semantic factors can trigger sound change. ${ }^{9}$ Anttila (1972: 77) suggests that "[b]ecause language is one organic whole ... where everything

\footnotetext{
8 See Jacobs (2005) for a more recent discussion of the Yiddish facts.

9 Anttila was not a generativist, of course, but is discussed here because of his endorsement of the idea of morphologically conditioned sound change.
} 
depends on everything else ..., it is logically thinkable that some sound changes would start from the grammar." In his view, denying the possibility of morphologically conditioned sound change implies that "only hearers are allowed to create change - not speakers, who come to sounds through the rest of the grammar" (Anttila 1972: 77). He further argues that a number of sound changes are morphologically conditioned, e.g. the loss of word-final nasals in Karelian, as such nasals are deleted, except in the genitive singular, as in forms like venehe- $n$ 'of a boat', compare illative vete-hen > vedeh 'into water', where the nasal is lost (Anttila 1972: 79). Anttila (1972: 79) links this change to grammatical marking: "[t]he $-h$ still remains to mark the illative, whereas the gen. $-n$ could not afford to lose anything. This is clear grammatical conditioning, because, phonetically, the endings of venehen and vetehen (these forms are the historically earlier forms, and they occur still in archaic or poetic Finnish) are exactly the same." Other potentially morphologically conditioned sound changes cited by Anttila include the retention of "endings that have been dropped from the nouns" in English, e.g. (the archaic form) whilom 'in former days', from OE hwīlum; incomplete phase formation in Rotuman; and vowel lengthening in Sanskrit. Further, Anttila argues that even the Neogrammarians allowed for morphologically conditioned sound change, claiming that they "had smuggled in" the idea, as they allowed word boundaries to condition sound change, even though "[w]ords are linguistic signs, and often their boundaries are not phonetically marked at all" (Anttila 1972: 78). Anttila of course does not demand that all sound changes be morphologically conditioned, and observes that "[e]ven if it is easy to formulate a grammatically conditioned sound change, it need not be historically correct" (Anttila 1972: 79) — a point taken up in several of the responses to the idea of morphologically conditioned sound change, as discussed below.

Contemporary responses to the idea of morphologically sound change were mixed. Some scholars seemed perfectly happy with the idea. Fudge (1972: 138-139) briefly summarizes Postal's discussion of Mohawk, stating that "Postal establishes that ... speakers must have distinguished between $k+w$ and the phonetically identical ordinary $k w$ on the grounds of morphological information alone.... This is sufficient to falsify [the strongest version of the Neogrammarian hypothesis]." Similarly, Robinson and van Coetsem (1973: 351), in a review article of King (1969), state that "King demonstrates that ... some sound changes do require more than phonetic information in their environments."

Other scholars were somewhat more cautious. Campbell (1971) was not happy with the Mohawk example Postal (1968) used in his argument, saying that it "is seriously challenged (vitiated, I think), by 
Chafe 1970" (Campbell 1971: 196). ${ }^{10}$ However, Campbell does not rule out morphologically conditioned sound change on principle, seeming to accept Lachmann's Law in Latin, as well as various sound changes found in the Uralic languages, as cases of it. ${ }^{11}$ Campbell also seems happy to accept the idea that semantic factors can influence sound change: certain types of words seem to be common exceptions to sound changes (proper names, onomatopoetic forms, nursery words, etc.), and cites a personal communication from Theo Vennemann to the effect that there are "German dialects in which pejorative items undergo a special sound change," as well as Ravila (1967), who "reports several such changes in Balto-Finnic languages" (Campbell 1971: 199).

Others were less happy with this idea. Jasanoff (1971), for instance, objects vigorously to it. Like Bloomfield before him, Jasanoff concedes that "in synchronic grammars there is a very real need for such rules" (Jasanoff 1971: 81), as in the case of Greek $s$ deletion, where $s$ is regularly deleted intervocalically except in the future and aorist of verbs, but argues that in diachronic terms they are better treated as the results of regular sound change that has been (partially) obscured by analogy. Like Campbell (1971), Jasanoff rejects the Mohawk example discussed by Postal and King, on the grounds that Chafe (1970) "has persuasively argued that the facts are open to an interpretation considerably more prosaic than the one which Postal and K[ing] place on them" (Jasanoff 1971: 81). As to King's Yiddish example, Jasanoff admits that an account based on analogy cannot be sustained, but argues in favor of a different reconstruction of the Yiddish data: in Jasanoff's view, final schwas that are deleted stem from Middle High German schwas, but final schwas that are not deleted stem from old long vowels regularly reduced to schwa. In Jasanoff's view, then, the examples cited by King (and by Postal) do not compromise the Neogrammarian notion of purely phonologically conditioned sound change, coupled with analogy and dialect borrowing.

\footnotetext{
${ }^{10}$ Chafe's interpretation of the Mohawk data has to do with the possible segmentation of some of the forms cited by Postal into morphemes, i.e. he argues that native speakers of Mohawk may parse these forms differently than Postal himself does.

11 Lachmann's Law is particularly interesting in this context, as Campbell's compromise on morphologically conditioned sound changes allows him to sidestep a different problem, namely rule insertion, i.e. whether rules could be added "not at the end of the phonological component" (King 1969: 43). That is, without allowing morphologically conditioned sound changes, rule insertion is necessary to account for the Latin data (cf. Kiparsky 1965 on this point). I plan to address the historiography of rule insertion in more detail elsewhere.
} 
Hock (1976) took a similar tack, contending that alternative accounts not involving morphologically conditioned sound change are available for the cases discussed in Anttila (1972). For instance, Hock suggests that there are some clear phonetic differences between the Karelian forms (they have different syllable structures and the length of the forms is also different), which "raises the possibility of a phoneticcum-analogical explanation" (Hock 1976: 215). As for English whilom, Hock (1976: 216) states that it "surely is nothing but a (clerical and/or poetic) archaism." Finally, on the idea that the Neogrammarians had "smuggled in" grammatical conditioning (Anttila 1972: 78), Hock (1976: 211) agrees with Anttila up to a point:

[Anttila's] is a justified objection to Neogrammarian PRACTICE: it is quite true that boundaries seem to have no direct phonetic correlates, and therefore are not proper environments for purely phonetically conditioned changes. But it remains to be proved that this Neogrammarian practice is NECESSARY.

Hock further argues that "the practice is (in most cases) not necessary," and proposes various alternative accounts, e.g. final devoicing might be "PHONETICALLY conditioned prepausal devoicing, plus subsequent generalization to environments with which pause usually coincides, i.e. word- or syllable-boundary" (Hock 1976; 211; one footnote was omitted). Hock (1976: 217) concludes that "unambiguous instances of grammatical conditioning are very rare and difficult to find." 12

The issue remains controversial, as demonstrated by the discussion of the topic in two relatively recent textbooks of historical linguistics. ${ }^{13}$ Sihler (2000) discusses the idea only tangentially: he distinguishes between sound changes and analogical changes, which hints that he would reject the idea of morphologically conditioned sound changes, but when he gets down to specifics (focusing on the Greek $s$ deletion mentioned above), he states that "it remains a topic of debate whether this is a 'therapeutic analogy' - that is, an innovation that restored intervocalic ${ }^{*} s$ after it was lost - or instead involved a continuous adjustment that prevented the consonant from being lost in the first place," i.e. whether Greek $s$ loss is a straightforward Neogrammarian sound change that has been partially obscured by later analogical change or a morphologically conditioned sound change (Sihler 2000:

\footnotetext{
12 In later work, Hock (1991) admits that there are problems with the Neogrammarian hypothesis, but ultimately rejects the idea of morphologically conditioned sound change in favor of the traditional Neogrammarian theoretical devices of regular sound change and analogy.

${ }^{13}$ Hill (2014) is another recent treatment of the topic.
} 
43). Campbell (2013) offers a somewhat more complicated picture: in his chapter on morphological change, he discusses the Greek case just mentioned, as well as a Mayan example, and remarks that "[w]hether sound change can be morphologically conditioned is disputed and remains an empirical question" (Campbell 2013: 263). In a later chapter, "Explanation," he returns to this question, discussing several cases of "well-known (putative) examples of morphological conditioning of sound change" (Campbell 2013: 326), from Greek, Estonian, Caribbean Spanish, and Saami, and ultimately punts (2013: 335), writing:

\begin{abstract}
At this stage of our understanding, we cannot ignore any potential causal factor ... and thus cut off inquiry before we arrive at a fuller picture of how and why changes occur. It will only be through further extensive investigation of the interaction of the various overlapping and competing factors that are suspected of being involved in linguistic changes that we will come to be able to explain linguistic change more fully.
\end{abstract}

\title{
5 The cause of the development
}

The final issue to address here is causality: why did some scholars abandon the strongest version of the Neogrammarian hypothesis in favor of a weaker version which held that some sound changes are morphologically conditioned? At least two factors played a role. First, consider the development of phonological theory since about the late 1950s. Where structuralist phonology was largely concerned with establishing the phonemes and allophones of individual languages, i.e. with representational matters, works like Halle (1959) and Chomsky \& Halle (1968) had largely shifted focus from representations to rules, i.e. holding that the phonological rules are more important than the phoneme system of a language, and couching these rules in terms of distinctive features, not necessarily in terms of phonemes. ${ }^{14}$ As the rules take on increasing theoretical importance, they are modified in ways that earlier theories would not have permitted. In light of the increasing application of generative linguistics to historical linguistics in the $1960 \mathrm{~s}$, it is thus unsurprising that the idea of morphologically conditioned phonological rules expanded into the idea of morphologically conditioned sound changes.

Secondly, consider the intellectual heritage and scholarly biographies of the linguists discussed here, as some of their scholarly orientations can be traced at least partly to intellectual influence. The

14 See Anderson (1985) for extensive discussion of this topic, as well as of the history of phonological theory in general. 
cases of Bloomfield and Sapir illustrate this point nicely. Trained extensively in Germanic and Indo-European linguistics at Harvard (B.A. 1906), Wisconsin (where he studied with Eduard Prokosch), and Chicago (Ph.D. 1909, with a dissertation on Germanic ablaut supervised by Francis A. Wood), Bloomfield eventually spent the 1913-1914 academic year in Leipzig and Göttingen, where he studied with a number of the giants of linguistics/philology, including August Leskien, Karl Brugmann, and Jacob Wackernagel (all good Neogrammarians). Sapir, on the other hand, took a different path. Sapir was educated at Columbia (BA [1904] and MA [1905]) in Germanic philology, with a master's thesis on Johann Herder's On the Origin of Language, but he eventually switched from Germanics to anthropology, getting a $\mathrm{PhD}$ in that field at Columbia in 1909, with a dissertation on Takelma (a native American language then spoken in Oregon; he had done field work in Washington and Oregon). This switch can be traced to Franz Boas, Sapir's adviser, as Sapir seems to have found the anthropological approach to linguistics more attractive than the Neogrammarian. Up until 1925 Sapir's work was very clearly dominated by anthropology (e.g. 1907-1908 he was a research associate in anthropology at Berkeley, and 1910-1925 he was head of the division of anthropology within the Geological Survey of the Canadian National Museum in Ottawa, now the Canadian Museum of Civilization). In sum, then, although trained somewhat in the Neogrammarian tradition, Sapir moved away from it at a relatively early stage of his career, embracing a newer approach to the field rooted in the study of Native American languages. Bloomfield, on the other hand, had considerably more extensive training in the Neogrammarian tradition, and remained committed to this theoretical model, his scholarly roots, and his methodological grounding for the rest of his career, despite the later shift in his research focus away from Germanic linguistics and philology (see Pierce 2009 on this point).

As for the more modern scholars - focusing on Postal, King, Anttila, Jasanoff, Hock, and Campbell - some of their situations are relatively straightforward, while for others the waters are a bit muddier. The straightforward cases are Postal, King, Jasanoff, and Campbell. Postal and King were both generative linguists, albeit with extensive training in more traditional approaches to linguistics. Postal, for instance, holds a doctorate from Yale, where American Structuralism dominated at the time (his doctorate in anthropology was awarded in 1962), but was simultaneously trained at MIT, where he 
taught from 1961 to 1965 . King, ${ }^{15}$ on the other hand, holds a doctorate in Germanic linguistics from the University of Wisconsin, with extensive early publications in traditional approaches to Germanic linguistics and structuralist ideas (e.g. King 1967a, 1967b). During the early stages of his time at the University of Texas however, King became close friends with Emmon Bach, author of the first textbook on generative syntax (Bach 1964),16 and from him learned about generative linguistics. For both Postal and King, then, their positive orientation towards morphologically conditioned sound changes is a straightforward extension of generative doctrines from synchronic phonology to diachronic phonology. In the case of Postal, his 1968 book also contains an extensive (and vicious) attack on structuralist approaches to phonology, meaning that the portion on sound change can, to an extent at least, be viewed as a backlash by Postal against what he viewed as a flawed approach to linguistics. As for Jasanoff, his training also accounts neatly for his orientation to the field, albeit from the other direction. That is, Jasanoff was trained at Harvard and in Bonn, both strongholds of traditional Neogrammarian approaches, and his rejection of morphologically conditioned sound changes is presumably a straightforward reflection of this. ${ }^{17}$ Finally, Campbell was a student of Raimo Anttila's at UCLA, whom he thanks in Campbell (1971: $191 \mathrm{fn} 1$ ) "for many long discussions which have helped me to clarify my thinking on many matters in historical linguistics; many of the ideas and examples I have used in this review are his." This again looks like a very straightforward case of a teacher influencing a student, reinforced by Campbell's exposure to the Finnish tradition of linguistics (Campbell has published extensively on Finnish).

The situation with Anttila and Hock, however, is trickier. They were both trained at Yale, where they both wrote dissertations supervised by Warren Cowgill (in 1966 and 1971, respectively). Cowgill himself was clearly a true believer in the Neogrammarian hypothesis. In his published work, Cowgill followed the Neogrammarian hypothesis closely and sometimes explicitly endorsed it. To take a few relevant examples, Cowgill (1959) relies on the Neogrammarian hypothesis and

\footnotetext{
15 Who, I should say here, is a former colleague of mine at the University of Texas at Austin.

16 This despite having written his own dissertation on Hölderlin's poetry.

17 Jasanoff's positive orientation towards generative linguistics is presumably the result of his extensive exposure to it as well; he remarks on his webpage that he attended Noam Chomsky's famous 1963 class that resulted in Aspects of the Theory of Syntax. Jasanoff further comments on his webpage that he was more inspired by Calvert Watkins, who eventually became his Doktorvater.(See http://www.people.fas.harvard. $\mathrm{edu} /$ jasanoff/about.html for details.)
} 
does not even hint at things like sporadic sound change or morphologically conditioned sound change; Cowgill (1978) offers some similar statements, e.g. his discussion of "a sound change which is perfectly regular but which, by the very nature of things, applies to just exactly one item" (Cowgill 1978:33); and he clearly endorses the Neogrammarian hypothesis in Cowgill (1985: 100), when in a discussion of Kiparsky's (1967) analysis of Greek verbal endings, he remarks that

\begin{abstract}
Kiparsky's rule is broader than it needs to be ...; and the details of its exact outcomes involve several options, in violation of the neogrammarian canon of Ausnahmslosigkeit der Lautgesetze. I believe that by making the rule more narrow, we can make it satisfactorily ausnahmslos, and at the same time throw some light onto other parts of Greek morphology.
\end{abstract}

Moreover, Alexander Lehrman, Cowgill's last doctoral student, states the following in his contribution to "Warren Cowgill as Teacher," published in Cowgill (2006):

\begin{abstract}
Warren was an unregenerate Junggrammatiker. He confessed it to his pupils at every opportunity. He firmly believed that the theory and the method as practiced by Karl Brugmann particularly - a photograph of Brugmann, magnified from his obituary in volume 39 of Indogermanische Forschungen, was, I think, the only picture in his office - were the only sound ones, period. Warren had little use for structuralism or for generative grammar, although he knew both thoroughly and used their idiom whenever and wherever it served his purpose.... Warren had tried all teachings, and he found that the ideas and methods of the Young Grammarians were the best - the most fruitful in understanding and demonstrating how actual languages actually work.
\end{abstract}

But if Cowgill was a Neogrammarian and trained his students as such, as Lehrman contends, why does one of Cowgill's most prominent students (Anttila) accept the idea of morphologically conditioned sound change, while another (Hock) rejects it? Cowgill's own published writings and statements on the matter contraindicate the idea that he would have taught Anttila one thing and Hock a different thing five years later, suggesting that the answer must lie elsewhere. One possibility is the idea that Anttila simply repudiated his own teachers' ideas and earlier training. ${ }^{18}$ While this may well be part of it, there are other factors which also bear consideration, including Anttila's scholarly background and earlier training.

18 I thank my own student Matthias Fingerhuth for reminding me of this. 
Anttila is from Finland, and was originally educated in Turku, and within Finnish linguistic circles, the idea of morphologicallyconditioned sound change has apparently been more widely-accepted than it was in American linguistic circles, at least at the time when Anttila was writing his textbook. In fact, Anttila (1972: 79) writes, "Clear evidence for grammatical conditioning comes from Baltic Finnic and Lapp [now called Sami, MP]; and in fact Finno-Ugric scholars have always used such information, even while it was theoretically undesirable in the mainstream of linguistic inquiry" (Anttila 1972: 79). Thus, we also see scholars like Ravila (1967) within the Finnish tradition, who argues that semantic factors can condition sound change. Hock, on the other hand, lacked this background, hence the different orientations: like Bloomfield, Hock and Anttila have both remained true to the approaches they were taught in their early careers, it is simply that they were taught different approaches.

\section{Conclusion}

The emergence of the idea of morphologically conditioned sound changes fits well with the development of generative linguistics as a field. That is, in the earlier years of generative grammar numerous structuralists felt that generative grammar offered an improved approach to syntax, one that could perhaps be coupled fruitfully with structuralist approaches to phonology. It was not until generative linguists moved into phonology that the real battles seem to have begun. Historical linguistics, on the other hand, remained somewhat more resistant to generative grammar, at least until the groundbreaking work of people like Postal (1968) and King (1969). ${ }^{19}$ The extension from morphologically conditioned synchronic phonological rules to morphologically conditioned sound changes, and the resistance to the idea of morphologically conditioned sound changes among historical linguists, reflects this development. Although a full historiographical treatment of this issue remains a desideratum, this paper represents a first step in that direction.

\footnotetext{
19 Jasanoff's views on morphologically conditioned sound change, then, could reflect this, even though he "accepts the validity of the generative model of language," albeit "with a few relatively minor reservations" (Jasanoff 1971: 79).
} 


\section{Comments invited}

PiHPh relies on post-publication review of the papers that it publishes. If you have any comments on this piece, please add them to its comments site. You are encouraged to consult this site after reading the paper, as there may be comments from other readers there, and replies from the author. This paper's site is here:

http://dx.doi.org/10.2218/pihph.1.2016.1702

\section{Acknowledgements}

I am grateful to Hans C. Boas and Patrick Honeybone for their help in the preparation of this paper. I also thank audiences at the Annual Meeting of the North American Association for the History of the Language Sciences (Minneapolis, Minnesota, January 2014), the Yale Conference on Baltic and Scandinavian Studies (New Haven, Connecticut, March 2014), and the Issues in the History of Historical Phonology Workshop (Edinburgh, United Kingdom, December 2015) for their comments. This work was supported financially by a Humanities Research Award and a College Research Fellowship from the University of Texas at Austin.

\section{Author contact details}

Marc Pierce

Department of Germanic Studies

University of Texas at Austin

2505 University Avenue, C3300

Austin, TX 78712-1802

USA

mpierc@austin.utexas.edu

\section{References}

Anderson, Stephen R. 1985. Phonology in the twentieth century: Theories of rules and theories of representations. Chicago: University of Chicago Press.

Anttila, Raimo. 1972. An introduction to historical and comparative linguistics. New York: Macmillan.

Bach, Emmon. 1964. An introduction to transformational grammars. New York: Holt. 
Bloomfield, Leonard. 1925. On the sound-system of Central Algonquian. Language 1. 130-156.

Bloomfield, Leonard. 1928. A note on sound change. Language 4. 99100.

Bloomfield, Leonard. 1930. German ç and x. Le Maître Phonétique 20. 27-28.

Bloomfield, Leonard. 1933. Language. New York: Holt.

Campbell, Lyle. 1971. Review article of King 1969. Language 47. 191209.

Campbell, Lyle. 2013. Historical linguistics. 3d edition. Cambridge, MA: MIT Press.

Chafe, Wallace. 1970. Review of Postal 1968. Language 46. 116-125.

Chomsky, Noam. 1965. Aspects of the theory of syntax. Cambridge, MA: MIT Press.

Chomsky, Noam \& Morris Halle. 1968. The sound pattern of English. New York: Harper and Row.

Cowgill, Warren. 1959. The inflection of the Germanic ō-presents. Language 35. 1-15.

Cowgill, Warren. 1978. The source of Latin vīs 'thou wilt'. Die Sprache 24. 25-44.

Cowgill, Warren. 1985. The personal endings of thematic verbs in IndoEuropean. In Bernfried Schlerath (ed.), Grammatische Kategorien: Funktion und Geschichte, 109-118. Wiesbaden: Reichert.

Cowgill, Warren. 2006. The collected writings of Warren Cowgill. Edited by Jared S. Klein. Ann Arbor: Beech Stave Press.

Fudge, E.C. 1972. Review of Postal 1968. Journal of Linguistics 8. 136156.

Halle, Morris. 1959. The sound pattern of Russian. The Hague: Mouton.

Hill, Nathan W. 2014. Grammatically conditioned sound change. Language and Linguistics Compass 8/6. 211-229.

Hock, Hans Henrich. 1976. Review article of Anttila 1972. Language 52. 202-220.

Hock, Hans Henrich. 1991. Principles of historical linguistics. Berlin: de Gruyter.

Jacobs, Neil. 2005. Yiddish: A linguistic introduction. Oxford: Oxford University Press.

Jasanoff, Jay. 1971. A generative approach to historical linguistics. Romance Philology 25. 74-85.

King, Robert D. 1967a. Functional load and sound change. Language 43. 831-852.

King, Robert D. 1967b. In defense of Klopstock as spelling reformer: A linguistic appraisal. Journal of English and Germanic Philology 66. 369-382. 
King, Robert D. 1969. Historical linguistics and generative grammar. Englewood Cliffs, NJ: Prentice-Hall.

Kiparsky, Paul. 1965. Phonological change. Cambridge, MA:

Massachusetts Institute of Technology dissertation.

Kiparsky, Paul. 1967. A phonological rule of Greek. Glotta 44. 109-134.

Labov, William. 1972. The internal evolution of linguistic rules. In

Robert P. Stockwell \& Ronald K.S. Macauley (eds.), Linguistic change and generative theory. 101-171. Bloomington, IN: Indiana University Press.

Labov, William. 1981. Resolving the Neogrammarian controversy. Language 57. 267-308.

Moulton, William G. 1947. Juncture in Modern Standard German. Language 23. 212-226.

Murray, Robert W. 2015. The early history of historical phonology. In Patrick Honeybone \& Joseph C. Salmons (eds.), The handbook of historical phonology, 11-31. Oxford: Oxford University Press.

Osthoff, Hermann and Karl Brugmann. 1878. Morphologische untersuchungen auf dem gebiete der indogermanischen sprachen I. Leipzig: S. Hirzel.

Paul, Hermann. 1920. Prinzipen der Sprachgeschichte. 5te Auflage. Halle: Niemeyer.

Paul, Hermann. 2015. Phonetic change. Translated by Robert W. Murray. In Peter Auer \& Robert W. Murray (eds.), Hermann Paul's 'Principles of language history' revisited. Translations and reflections, 59-82. Berlin: de Gruyter.

Pierce, Marc. 2009. Leonard Bloomfield's contributions to Germanic linguistics. Beiträge zur Geschichte der Sprachwissenschaft 19. 212140.

Postal, Paul. 1968. Aspects of phonological theory. New York: Harper and Row.

Ravila, Paavo. 1967. Totuus ja metodi: Kielitieteelisiä esseitä. Porvoo: Söderström.

Robinson, Orrin W. III. 2001. Whose German?: The ach-ich alternation and related phenomena in standard and colloquial. Amsterdam: Benjamins.

Robinson, Orrin W. III \& Frans van Coetsem. 1973. Review article of King 1969. Lingua 31. 331-369.

Sapir, Edward. 1921. Language. New York: Harcourt, Brace, and Company.

Sihler, Andrew. 2000. Language history: An introduction. Amsterdam: Benjamins.

Weinreich, Uriel, William Labov \& Marvin Herzog. 1968. Empirical foundations for a theory of language change. In Winfred Lehmann \& 
Yakov Malkiel (eds.), Directions for historical linguistics, 95-198. Austin: University of Texas Press.

Wilbur, Terence H (ed.). 1977. The Lautgesetz-controversy. A documentation (1885-1886). Amsterdam: Benjamins. 